\title{
The Mass Media Reportage of Crimes and Terrorists Activities: The Nigerian Experience
}

\author{
Chika Euphemia Asogwa ${ }^{1}$, John I. Iyere ${ }^{2} \&$ Chris O. Attah ${ }^{1}$ \\ ${ }^{1}$ Department of Mass Communincation, Kogi State University, Kogi State, Nigeria \\ ${ }^{2}$ Department of Philosophy and Religious Studies, Kogi State University, Kogi State, Nigeria \\ Correspondence: Chika Euphemia Asogwa, Department of Mass Communincation, Kogi State University, \\ P.M.B. 1008, Anyigba, Kogi State, Nigeria. Tel: 234-81-3004-7065. E-mail: euchika@yahoo.com
}

Received: November 25, 2011 Accepted: December 26, 2011 Online Published: July 1, 2012

doi:10.5539/ach.v4n2p175 URL: http://dx.doi.org/10.5539/ach.v4n2p175

\begin{abstract}
The new mass media technologies now make information processing and distribution more accessible to people globally. Marshall Mcluhan's "global village" has given birth to a "global palour". However, perpetrators of crimes now bask on the philosophy of communication media practitioners that people have the right to know what is happening within and outside their environment. This stance is rapidly dismantling, in an amazing fashion, the hitherto accorded respect for media ethics. Neil Postman, a New York media analyst, describes the creator of technology as the list judge of its consequences, especially with regards to the technology of the media. True, every communication medium is potent with the possibility of occasioning other consequences not directly intended by it. This paper, therefore, attempts to bring to the fore the way communication media are inadvertently promoting crimes and terrorist activities globally. It is the stand of this paper that a global overhaul of mass communication media is needed for balance reportage that would bring about global and meaningful developments of human and material resources under an atmosphere of peace and mutual tolerance.
\end{abstract}

Keywords: Nigeria, mass media, reportage, crimes, terrorism

\section{Introduction}

The coverage of crime has always been a complex issue for the media and in this era of Information and Communication Technologies (ICTs) the coverage of terrorist's activities has become an even greater concern. Undoubtedly, the global nature of our new communication technologies has brought about easy and quick access to information. Both peace lovers and perpetrators of evil activities are caught in this inevitable wed of information packaging and dissemination. Adora (2010) commenting on the worrisome nature of terrorism globally has this to say:

... We live in a world of strife, violence and wars. Despite the untiring effort of individuals, groups, organizations and countries all over the world to promote peaceful co-existence among men and women, our generation is still being threatened by the ravage of terrorism. Indeed, the phenomenon of terrorism today is something that is most disturbing and calls for renewed counter terrorism approaches (p. 103).

Critically, the positive and negative effects of the many messages the mass media send out about crime and terrorism on daily basis to consumers are not often given top priority. What seems to matter to mass media practitioners is to write or broadcast the latest happenings under the philosophy that the people have the right to know what is happening within and outside their environment. Looking at this stance of the media practitioners closely one is provoked to ask these questions. How are the mass media practitioners or gatekeepers sure that what the "global public" wants is given to it in terms of information distribution? How are they sure that their audiences like the way and manner criminal and terrorists activities are enthroned on the media podium of Agenda - Setting theory? How often do mass media practitioners applaud or celebrate on daily basis promoters of universal peace, and remarkable meaningful developments, especially in the less developed nations of the world? 
The main concern of this paper is to highlight how the mass media, especially electronic media, have inadvertently contributed to the escalation of crimes and terrorists activities. Particular reference is on Nigeria in this paper while leaning on global events of terrorism.

\section{Theoretical Framework}

For a better discussion on the topic of this paper two theories have been chosen. They are: (i) Agenda-Setting and (ii) Uses and Gratifications theories. Their main view points are briefly highlighted because of the limited scope of the paper.

\subsection{Agenda - Setting Theory}

This theory is credited to two researchers Donald Shaw and Maxwell McCombs in the 1970s who studied people's reactions to election campaigns through the media $(1972$, p. 176). In this theory "it is assumed that the more attention the media give to a topic, the greater is the importance attributed to it by the news audience" (McQuail, 2010, p.548). This simply put means that if the media give much air-time or space (in a repetitive manner) to an issue or event it is seen by information consumers as very important (Baran, 200, p. 327). This theory is significant in this paper because terrorists and international criminals know the power of the mass media and therefore use them to their advantage by committing destructive activities or crimes which the media have to report. In this respect the media need the terrorists and the terrorists need the media to reach out to the public.

\subsection{Uses and Gratifications Theory}

In the views of McQuail (2010) the main thrust of this theory is that audience members have certain needs or drives that are satisfied by using varied media sources. And this is a version of "individualist functional theory" and that of "active audience theory" which has been used in the study of media effects on users. The question is not what media do to their scattered audiences but how they (consumers) made use of the media. This theory is appropriate in this study because both terrorists and non - terrorists audiences often seek to satisfy their various needs. The terrorists are pleased to hear or view their destructive activities being aired or relayed by the media. By this their ideologies are also disseminated to the public. Non-terrorist audiences fill that the media have to tell them or inform them of what is happening in their environment. It follows, therefore, that terrorists, criminals and ordinary audience need the media to satisfy their needs, and the effects can be positive and negative (Hoffman, 2007, p. 306).

\section{The Concept of Terrorism}

The word "terrorism" is subject to many definitions and as such there is no universal agreed meaning. What in some quarters perceive as terrorism may be regarded in other quarters as political or religious freedom fighters who want to be heard and solutions found to their agitations. This paper therefore limits itself to the definition given by the United Nation's (UN) office for Drugs and Crime Prevention. It states in 1992 that terrorism is (Adora 2010, p.103):

An anxiety - inspiring method of repeted violent action, employed by (Semi) Clandestine individuals, group or state actors, for idiosyncratic, criminal or political reasons, whereby - in contrasts to assassination, the direct targets of violence are not the main targets. (International Terrorism/Security |Research 1-3).

Equally, this paper also takes cognizance of the African Union's (AU) conception of terrorism. It defines it (Oyeniyi, 2010) in article 1 (3) as:

Any act which is a violation of the criminal laws of a state party and which may endanger the life, physical integrity or freedom of, or cause serious injury or death to any person, any number or group of persons or causes or may cause damage to public or private property, natural resources, environmental or cultural heritage... (p. 3).

The article goes further to say that the action of the terrorist must be a calculated or intended to:

a. Intimidate, put in fear, coerce or induce any government, body, institution, the general public or any segment thereof, to do or abstain from doing any act or to adopt or abandon a particular standpoint or to act according to certain principles; or

b. Disrupt any public service, the delivery of any essential service to the public or to create a public emergency or;

c. Create general insurrection in a state. 
Bearing in mind the above definitions one would be right to say that the world is presently riddled with many terrorist activities. There seems to be no day passed without graphic reports of terrorists destructive activities globally. Most countries of the world are daily designing strategies to curb the intrinsic menace of terrorism. Critically, man's inhumanity to man seems to be on the increase as man advances in science and technology. Instruments of our civilization are now being used to destroy the products and resources of our developments. Terrorism which we consider as man's inhumanity to man started many years age or should we say it is as old as mankind (Adora, 2010). Wikipedia Encyclopedia $(1-10)$ gave some account of the emergence and activities of terrorism in some countries. With reference to African Continent every country in it has directly or indirectly experienced the activities of terrorists. Oyeniyi (2010) talking about terrorism in African states:

...terrorism has had a long history in Africa. From the Sherifian dynasty of the Alawites and Filali in Morocco to the Regencies of Algeria, Tunisa and Libya under the effecte Suzerainty of the Sultan of Turkey, the Berber-Arab population of North Africa experienced one form of terrorism after another, even before the colonial rule. The French invasion of Algeria in 1830, the establishment of French rule in Morocco in the 1900s and their occupation of Tunsia in 1880 were all characterized by one terrorist acts after another (p. 1).

Oyeniyi equally maintained that countries of East Africa, South Africa, and West and Central Africa have experienced various levels of terrorism (p.1). The attention of the world was drawn to Nigeria when a 23 year old Nigerian Farouk Abdulmuttalab attempted to bomb an airline in the United States of America December 2009. Nigeria was then looked upon as one of the "terrorist nations" by America and some other nations. Though Nigeria's name was later removed from the list of terrorist nations after strong diplomatic meetings, the facts at our hands now with Boko Haram (Islamic religious sect) series of bombings have put back Nigeria's name. Both national and international media are now making series of headlines on Boko Haram's terrorist activities (Ibrahim, 2011, pp.14-20).

\subsection{Public Right to Information Principle}

The mass media are regarded as the "Fourth Estate of the Realm". It goes to show the important place the press or the mass media occupy in the world affairs. It is the basic duty of the media to inform, educate and entertain the public. Under these basic functions media practitioners now strongly believe that the people have the right to know what is happening around them. This principle has opened the gates to all sorts of information distribution to the public not minding their negative effects on the public. The new information technologies now enable media practitioners (journalists) relay events from any part of the globe as they are unfolding. The raw nature of the events, including terrorist activities, is sent down to many homes. Live broadcast is now the hallmark of television industry solidly aided by new mass media technologies. The $9 / 11$ terrorists attack in United State, the recent killing of Osama Bin Laden by US special force and the Boko Haram bombing of Police Headquarters in Abuja, Nigeria on 16 June, 2011 are just few examples. The negative effects violent events have on television viewers no longer mean anything to media practitioners. Media ethics seem not to matter anymore, but sensationalism does fueled by the competitive nature of media houses today.

Commenting on media ethics Mc Quail (2010) says:

... media can and should be held to account for the quality, means and consequences of their publishing activities to society in general and/or to other interests that may be affected. This brings accountability into potential conflict with freedom (p.562).

Surely, the media have to perform their surveillance duty by giving us information we need to live, and warn us about dangers to our state of living. They (media) are supposed to be the watch-dogs of the society (Hoffmann, 2007). However, the media's dysfunction with regards to crime and terrorism make people think that the world is unsafe to live in. This is because most people believe that what the media present to them is absolute truth. The pictures about events in the world presented by mass media are therefore seen as authentic. Because of the powerful nature of new media of information many political leaders lean heavily on them afraid to control their excesses. Such leaders and media products consumer now comfortably hide under the spiral of silence theory (Noelle-Neumann, 1984). These must not be allowed to continue. Something positive has to be done. The mass media practitioners should not in the name of democracy and freedom of the press throw media ethics to the dust bin. Coverage of crimes and terrorists activities needs high level of decency and discipline.

\subsection{Terrorism and Sensationalism}

Terrorists have varied ideologies which they want to implement. These ideologies could be political, religious, ethnic and so on. But one thing that is common to them is sensationalism. They want as many people as possible 
to know about their existence and their ideologies. To this end they carry out massive havoc that would attract media attention, or send out continuous threats to the public through the media. The reportage of such terrorists events or strategies would inevitably cause some panic among the immediate target audience and fear in the minds of those far away. The point we are projecting here is vividly captured in these words of Boaz (2000):

Terrorists are not necessarily interested in the deaths of three, or thirty - or even of three thousand - people. Rather, they allow the imagination of the target population to do their work for them. In fact, it is conceivable that the terrorists could attain their aims without carrying out a single attack; the desired panic could be produced by the continuous broadcast of threats and declarations - by radio and TV interviews, videos and all the familiar methods of psychological warfare (http://www.terror.gen.tr/English/USA articles. pp. 1-17).

The faceless "leaders" of Boko Haram recently sent messages to some media houses in Nigeria listing the names of highly placed personalities that they would kill. The broadcast of such names has sent some fears in the minds of those concerned and the general public. The questions that come to one's mind are: Why broadcast such names? Are the Nigerian media not indirectly promoting the activities of this terrorists group? We subscribe to the views of Nacos (2000) that:

With massive news coverage the terrorist act would resemble the proverbial tree falling in the forest: if no one learned of an incident, it would be as if it had not occurred (p.175).

The kidnapping situation in Nigeria has become a worrisome issue because of the way the criminal gangs are using the media to put fears in the minds of the public. Media coverage of their various kidnapping episodes give the desired sensational posture. Through the mass media the kidnappers know the efforts the law enforcement agents are making to smoke them out from their hideouts. No doubt, such information would make the criminals to redesign their strategies and locations - thereby putting victims in precarious situation which sometimes can lead to their death or serious harm.

\subsection{Terrorists and Media Relationship}

The relationship between the media and terrorists has been very cordial in this era of globalization being propelled by new media of communication. As we alluded to earlier terrorists are very much aware of the tremendous strength of the media. They (terrorists) are conscious of the formidable amplification that media reportage adds to any event or issue - relatively small scale violence witnessed by many can have effects greater than large scale violence witnessed only by few. Indeed, many terrorist activities provide mass media practitioners with the dramatic features of a news- worthy story. The terrorists acts, one would say, are nothing publicity is all. In the views of Schmid and de Graat (1982) the media are not simply gatekeepers, neutral or complicit with either state or terrorists, but rather are active agents in the process of the construction of information. The symbolic relationship between the mass media and terrorists is greater in the developed countries than in the less developed ones.

Furthermore, it is quite interesting to know that many outputs of media coverage of terrorism seem suggestive. Terrorists activities are often labeled in a positive manner; while terrorism actors are "terrorists", "saboteurs," and "murderer", in the victim country, they may be "freedom fighter", "liberation movement members", "separatists", or "nationalists" in the foreign media. Locker (2003, p. 2) gave some examples of Terrorist and Counter-Terrorist labels and nomenclature for the same things:

Table 1. Terrorist and counter-terrorist labels and nomenclature for the same things

\begin{tabular}{llll}
\hline 1 & Criminal - Revolutionary & 9 & Threat - Warning \\
2 & Terrorist - Guerrilla & 10 & Aggression - Preventive Counter Strike \\
3 & Murderer - Freedom fighter & 11 & Assassin - Avenger \\
4 & Gang - Army & 12 & Propaganda - Communiqué \\
5 & Subversive element - Liberator & 13 & Extremist Fanatic - Dedicated Anti- Imperialist \\
6 & Blood Bath - Purge & 14 & Attacks - Operation \\
7 & Lunatic - Martyr & 15 & Hired Killer - Example of Revolutionary \\
8 & Mercenary - Soldier & 16 & Murder - Revolutionary Justice. \\
\hline
\end{tabular}


In this respect, terrorists do benefit from what Merton (1949) calls "status conferral function". His view is that:

The audience of mass media apparently subscribe to the circular belief that if you really matter, you will be at the focus of mass attention and if you are at the focus then surely you are really matter (pp. 95-118).

Most terrorists worldwide today value modern media of communication very highly because through them their ideologies and the results of their deadly attacks are communicated to the public locally and internationally. These make the terrorists popular and feared. And the media are happy to relay terrorists events to the public, because they consider them newsworthy. BBC, CNN, Al Jazeera, Press TV, NTAI, Channels and many other media organizations (including print) on daily basis write and broadcast terrorists activities. Prime time and Front headlines are often given to crimes and terrorists events under Agenda - Setting platform. Is a false world not being created by our mass media in this era of globalization by overloading the public with crimes and terrorists activities? This question is answered in part by the work of George Gerbner on TV portrayal of violent programmes (Hanson, 2005):

- Violent programming pushes aside other ways of portraying conflict.

- Violent programming deprives viewers of other choices.

- Violent programming facilitates the victim mentality.

- Violent programming discourages production of alternative programming (p.260).

We tend to agree with the above stated points summarized from George Gerbner's research work. We think that the media should not write or broadcast detailed aspects of terrorists and criminal activities, especially the ones that would lead to psychological problems for viewers. The media we believe can exist without terrorism. That is to say that the media do not need terrorists to carry out their duty of information dissemination. But the terrorists would not exist in the minds of many if the media do not give them coverage. Presently terrorists are having a "good-day" because of the undue publicity given to them. Most terrorists often play on the psychology of media practitioners by carefully planning attacks that would compare them to cover and disseminate globally. Nacos (2000) is worth quoting here when he observed that:

Since the most gruesome and deadly incidents receive the greatest volume of reporting, media critics have charged that terrorists resort to progressively bloodier violence to satisfy the media's appetite for shocking news (p. 176).

In the bid for media to look for newsworthy stories they "should be mindful of their ethical codes". This seems to be what the silent majority of media consumers tend to be saying. The high rate of competition among modern media also gives legitimacy to terrorists acts. In order to get a wider audience and advertisement high rate most media today directly and indirectly fan the embers of terrorism, and thereby jeopardizing law enforcement agents, and stakeholders plans to combat terrorism from various angles. In fact, sometimes some journalists and broadcasters disseminate vital information from governments, and security agents on how, where and when to deal with particular terrorist groups. When such information gets to the terrorists they re-plan their strategies and cause more havoc on people and property. The recent Boko Haram Islamic sect suicide attack on Police Headquarters in Abuja on June 11, 2011 is an example. Some of the Nigerian media reported on many occasions how the Inspector General of Police (IGP) said he was prepared to deal rootlessly with Boko Haram group. The group (Boko Haram) carried out the suicide bomb attack to show the Inspector General of Police (IGP) that his security strategies were porous. He was not on "top of the situation" as he often claimed to be (Abu 2011, p.7). The most recent of the attack of the Boko Haram sect is the bombing of the UN house in Abuja, Nigeria on the $28^{\text {th }}$ of August, 2011.

Ockrent's (2006, p.75) comments firmly capture our argument presented above. He notes that:

All the news networks are very competitive, and their treatment of news is more and more like that of tabloids. (...) Moreover, speed is of the essence. We are no longer bewildered to see an event on the screen before we know what has actually happened. The development of headlines news helps terrorism have an immediate impact upon a vast number of people.

The mass media no doubt have a larger public than terrorists. The media cannot exist without the said public that looks onto them for proper information dissemination that would lead to national security and meaningful developments. It is a pity that the wide coverage given to terrorists events by the media is not given to peace-builders, conflict resolution bodies and developmental feats in less developed countries. 


\subsection{National Development and Security}

Human beings are highly endowed with the capability for development. Each decade gives birth to new developments so as to make the world a peaceful and enjoyable place for all. Sad enough, human beings themselves occasionally bring about massive destructions of what it took many years to build. By this act of barbarism mankind tends to slow down the wheel of progress. Indeed, "globalization in its many forms is as a result of mankind's efforts to develop the world positively, and conquer nature's multiple challenges" (Iyere 2006, p. 380).

No nation worth its salt can execute meaningful projects in an atmosphere devoid of peace. Peace and security of lives bring about developments. Any nation whose national security is poor would always be greeted with volumes of conflicts that would divert the government's attention from carrying out developmental policies and their execution. Many countries today are faced with criminal and terrorists activities leading to heavy human casualties and destruction of natural resources. Many people would not like to invest or do business with a country noted for terrorists attacks or conflicts. For example one would not like to carry out reasonable business or go on vacation to places like Iraq, Yemen, Morocco, Dubai, Tunisia, Libya, Afghanistan, Syria, Guinea, Norway and so on to list just a few. The reason being that these places are riddled with crises leading to killings and massive destruction of natural resources. The governments of such places have no time to devote their energy for constructive developments that would lift the living standard of the people. With particular reference to Nigeria, the Niger-Delta crisis seriously affected the economy of the nation. Most of the oil wells or industries did not function as expected and as such Nigeria could not export enough crude oil which we greatly depend on. However, with the introduction of amnesty for the militant groups peace has returned to the area, and export rate of the crude oil is now high. Furthermore, the Boko Haram group, based in Borno State, is causing havoc almost on daily basis in the nation's capital Abuja and many parts of the States in the north (Ibrahim, 2011). Meaningful developments in such areas are put on hold. Attention is now diverted to finding solutions to the Boko Haram saga. The national security is really at stake with this terrorists group that hates western education. Commenting on Boko Haram the former President Olusegun Obasanjo (2011) states:

The nation requires adequate information on the activities of the Boko Haram sect, the motive behind their actions, and their sponsors before the problem could be effectively tackled. We must not take this for granted as the lives of majority of Nigerians are on the risk (p.5).

The views of Obasanjo and others should be taken seriously by the Federal Government, because if adequate measures are not formulated foreign investors would not do business with Nigeria. Surely, we need foreign investors in our States and National developments. A peaceful atmosphere needs to be created for developments to take place. Because of corruption rooted in our national fabric money meant for security are not properly utilized. As a result criminals are having the needed liberty to operate in most parts of our country today. Political thugs, kidnappers, and armed robbers have planted themselves firmly on Nigerian soil. The more the Nigerian media report their activities the more they perpetrate their evil acts. Condemning these evil acts on the pages of news papers and on television is not enough - pragmatic steps have to be taken to reduce the menace to low ebb.

\section{Conclusion}

In this paper we have looked at the global phenomenon of terrorism and the inadvertent role of the mass media in its promotion thereby jeopardizing national security. It is our stand that the media can exist without undue coverage of terrorists devastating activities. But without the mass media's coverage terrorism would not exist in the minds of many people as it is today under the canopy of "Agenda-Setting and Framing". We thus advocate that less coverage should be given to terrorists inhuman activities which often make people think that the world is no longer safe to live in. Media coverage, among other things, should focus more on developmental feats, peace makers, and conflict-peace resolution bodies. We firmly believe that no meaningful developments can see the light of day in a society devoid of transparency, unity, equity, love and human dignity.

\section{Recommendations}

We present here some recommendations based on our above discussion.

- Media practitioners should constantly bear in mind their professional ethics under the umbrella of media code of conduct. This would help check-mate unnecessary coverage of criminal and terrorists activities. 
- As watch-dogs (the Fourth Estate of the realm) of the society mass media practitioners should promote transparent democratic governance and bring to the public view of political and religious leaders who fan the embers of criminal and terrorist destructive activities.

- Well trained journalists on crime coverage should be the ones allowed to do so. Such journalists by their training would know what are ethically and psychologically proper to disseminate to the public.

- Journalists should as a matter of national security not write or broadcast unguided utterances of security agents with regards to logistical plans to root out criminals and terrorists from our civilized society. The Wiki- leak's publication of secret documents of some governments some time ago has generated bad blood among many countries in the world. The publication really put national security at risk and seriously affected international relations.

- Our media practitioners as a matter of agenda-setting should promote the basic doctrines of love, peace, universal brotherhood, freedom, justice, human rights, patience, tolerance, equity and non-violence. Where all these are enthroned national security and the development of human and material resources would be the order of the day.

\section{References}

Adora, C. U. (2010). Renewing the face of Counter Terrorism for Global Peace: The Challenges for Theatre Artist in Nigeria. Jos Journal of Humanities, 4(1), 103- 114.

Abu, B. D. (2011, July 4). Let's Talk. Newswatch, 7.

Baran, S. J. (2001). Introduction to Mass Communication: Media Literacy and Culture. California: Mayfield Publishing Company.

Boaz, G. (2002). USA and Terrorism (1-17). Retrieved from http://www.terror.gen.tr/English/USA articles.

Blumber, J. G. (1992). Television and the Public Interest. London: Sage Publications.

Gerbner, G. (2000). Television Violence and the Art of Asking the Wrong Question. Center for Mass Media Literacy website.

Hanson, R. E. (2005). Mass communication. Living in a Media World. New York: The McGraw-Hill Companies.

Hoffmann, B. (2006). Inside Terrorism. New York: Columbia University Press.

Iyere, J. (2006). Religious Management as a Tool for Global Peace. In D. Stinton (Ed.), The Arts, Man and Globalization: Trends, Issues and Problems (pp. 377-385). Accra North: Deocraft Communications.

Ibrahim, I. (2011, August 1). The Boko Haram Killings. The News Watch, 1-20.

Locker, A. (2003). The Relationship Between the Media and Terrorism. Retrieved from www.transcationalterrorism.eu

Merton, R. K. (1949). Patterns for influence, in Social Theories and Social Structure. Glencoe, IL: Free Press.

McCombs, M. E., \& Shaw, D. L. (1970). The Agenda - Setting function of Mass Media. Public Opinion Quarterly, 36, 176-187.

McQuail, D. (2010). Mass Communication Theory (6th ed). London: Sage.

Nacos, B. (1994). Terrorism and the Media. New York: Columbia university press.

Noelle, N. E. (1984). The Spiral of Silence: A theory of Public Opinion. Journal of Communication, $24,24-51$.

Obansanjo, O. (2011, July 8). How to deal with Boko Haram. The Daily Sun (p.5).

Ockrent, C. (2006). Terrorism and the Media. Retrieved from www.transnationalterrorism.eu/tekst/publications/WP4\%20Del\%206.pdf

Oyeniyi, A. B. (2010). Terrorism in Nigeria: Groups, Activities, and Politics. International Journal of Politics and Good Governance. 1(1), 1-16.

Schmid, A., \& de Graaf, J. (1982). Violence as Communication: Insurgent Terrorism and the Western News Media. London: Sage.

Wikipedia Encyclopedia. (2011). Terrorism. Retrieved from http://en/wikipedia.org/ukw 